The Haunt of Home 


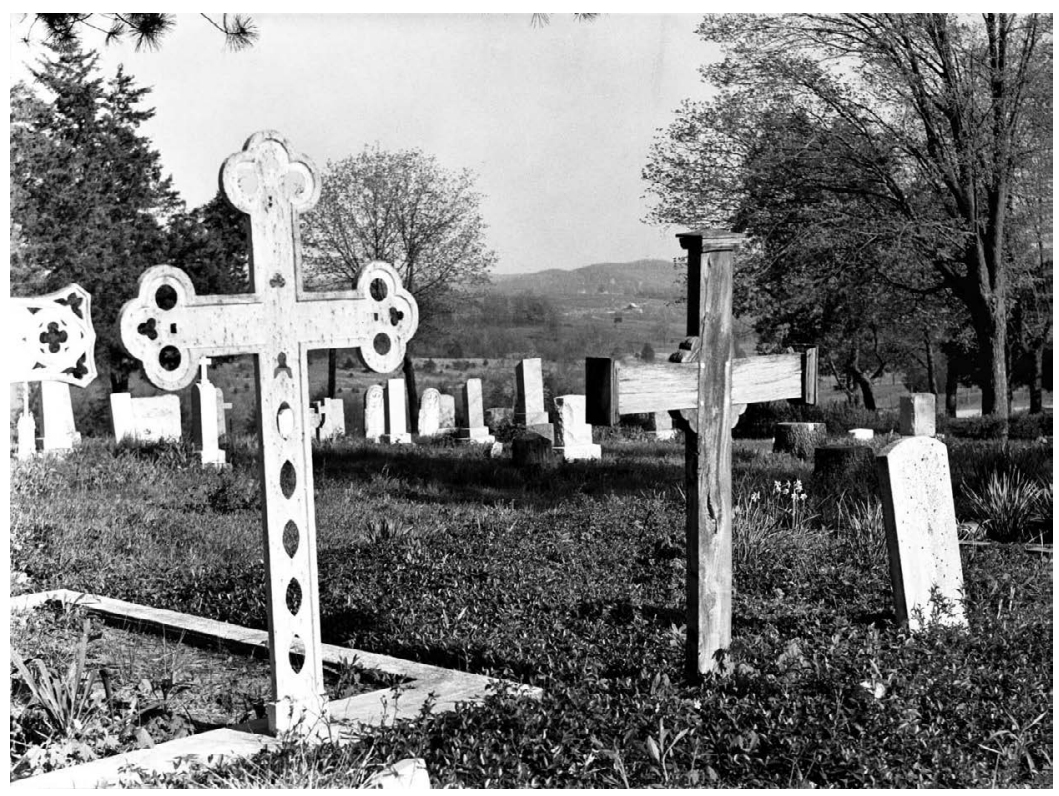

Cemetery, Starkenburg, Montgomery County, MO. From Historic American Buildings Survey, Library of Congress, HABS MO,70-STABU.1-, https://www.loc.gov/item/mo0815/. 


\section{The Haunt of Home}

\section{A Journey through America's Heartland}

\section{ZaCHARY MichaEL JaCK}

Northern Illinois University Press AN IMPRint OF CORNell University Press ITHACA AND LONDON 
Copyright $\odot 2020$ by Cornell University

All rights reserved. Except for brief quotations in a review, this book, or parts thereof, must not be reproduced in any form without permission in writing from the publisher. For information, address Cornell University Press, Sage House, 512 East State Street, Ithaca, New York 14850. Visit our website at cornellpress.cornell.edu.

First published 2020 by Cornell University Press

Printed in the United States of America

Library of Congress Cataloging-in-Publication Data

Names: Jack, Zachary Michael, 1973- author.

Title: The haunt of home : a journey through America's heartland /

Zachary Michael Jack.

Description: Ithaca, [New York] : Northern Illinois University Press, An imprint of Cornell University Press, 2020.

Identifiers: LCCN 2020002991 (print) | LCCN 2020002992 (ebook) | ISBN 9781501751790 (paperback) | ISBN 9781501751806 (epub) | ISBN 9781501751813 (pdf)

Subjects: LCSH: Place (Philosopy). I Fate and fatalism. I Middle WestBiography-Anecdotes. I Middle West—Social life and customs I Middle West-In literature.

Classification: LCC F351 .J33 2020 (print) I LCC F351 (ebook) | DDC 977-dc23

LC record available at https://lccn.loc.gov/2020002991

LC ebook record available at https://lccn.loc.gov/2020002992

Cover image $\odot$ Liz Weddon/Unsplash 
To Grant Wood, and to Mom, maestros both in my book 

Life was not a valuable gift, but death was. Life was a fever-dream made up of joys embittered by sorrows, pleasure poisoned by pain; a dream that was a nightmare-confusion of spasmodic and fleeting delights, ecstasies, exultations, happinesses, interspersed with longdrawn miseries, griefs, perils, horrors, disappointments, defeats, humiliations, and despairs - the heaviest curse devisable by divine ingenuity; but death was sweet, death was gentle, death was kind; death healed the bruised spirit and the broken heart, and gave them rest and forgetfulness; death was man's best friend.

- Mark Twain, Letters from the Earth 
